\title{
A Critical Review of the Concepts Associated with Women Entrepreneurs in Rural Areas
}

\author{
Tebogo Mogashoa
}

\author{
University of South Africa, College of Education, Department of Curriculum and Instructional Studies \\ PO Box 392, 0003 Unisa, South Africa \\ Email: mogasti@unisa.ac.za
}

\section{Doi:10.5901/mjss.2014.v5n23p2263}

\begin{abstract}
The aim of the research was to critically review concepts associated with women entrepreneurs in rural areas in the Mpumalanga Province of the Republic of South Africa. This study was underpinned by a conceptual model developed by Howie (2003) on effectiveness in order to foreground possible factors influencing entrepreneurship in rural areas. A positivistinterpretive quantitative research approach was employed for the purpose of conducting this study. A structured questionnaire, as a data collection technique, was used to collect the women's opinions. Descriptive statistics was used to summarize, organize and reduce large numbers of observations extricated from the participants' questionnaires. It has been established in this study that through much of its history, rural South Africa has been home to small-town merchants, talented crafts people and progressive farmers, all willing to take the risks necessary to build their business and live the life of their choice. Business success often depends on the existence of an enabling environment on one hand and the possession of skills and competencies by the entrepreneur on the other. The general lack of planning for resources by rural women entrepreneurs is a great contributing factor to the development of rural women entrepreneurs in rural regions. There is a need for encouraging active participation among rural women into business as they form key targets for economic development in rural areas.
\end{abstract}

Keywords: Empowerment, entrepreneurs, quantitative, environment, financial constraints.

\section{Introduction and Context of the Study}

Women are increasingly assuming a bread wining role in most households in South African societies. They contribute to the growth and development of small business ventures. Most of women businesses are run largely on an informal basis, lacking in proper book keeping and general business management skills and they collapse before reaching the maturity stage. Small business requires some special qualities for it to be successful. Most of these qualities are held in what is termed as entrepreneurial spirit, the everlasting life elixir that prevents stagnation and eventual collapse of business. The women entrepreneurial development in rural areas seems to be falling short of meeting the general public expectations. There is wide evidence of lack of entrepreneurial skills, marketing skills, planning skills and financial constraints among women entrepreneurs (Sizoo 2000:412). Poor economic situation and movement of young and educated people from rural to urban areas are some of the factors contributing to the lack of strong culture of entrepreneurship in the rural areas. Moe (2003:3) stipulates that women and families were virtually ignored in economics before the 1960s, and many argue that they continue to be marginalized in economics theory today. The reason for conducting this study is to contribute to the body of existing knowledge concerning the development of women entrepreneurship in rural areas. This study will be a useful tool for women who operate small businesses in the rural areas by providing data that will empower them. Thus the researcher sought to critically review concepts associated with women entrepreneurs in rural areas.

\section{Theoretical Frameworks}

A conceptual model developed by Howie (2003) on effectiveness was employed in order to foreground possible factors influencing entrepreneurship in rural areas. This model shares the same sentiments with the one developed by Heneveld and Craig (1996). Howie's model comprises three facets (Inputs, Processes and Outputs) and serves as a significant theoretical and conceptual basis for the analysis of the study. Howie's model is, to a greater extent, informed by the work of Shavelson, McDonnell and Oakes (1987). The inputs comprise policy-related contexts operational at the national, regional and local level that inform the design and development of the intended policies on women empowerment. In retrospect, central to Howie's model are the input, processes and output. The main input, as per this model, that the study focused on was the rural woman entrepreneurship. A lack of appropriate and competent input has a negative effect on 
the attainment of outcomes.

\section{Research Design and Methods}

A positivist-interpretive quantitative research approach was employed for the purpose of conducting this study (Maree 2007:21). The study also drew from applied research and empirical quantitative research methods to collect data. Empirical means guided by evidence obtained from systematic research methods rather than opinions or authorities (McMillan and Schumacher 2010:9). Applied research is concerned with the application and development of researchbased knowledge about some particular practice (McMillan and Schumacher 2010:13). It produces knowledge pertinent to providing solutions to a broad-spectrum of problems (McMillan and Schumacher 2010:13). De Vos, Strydom, Fouché and Delport (2002:138) contended that quantitative research encompasses experiments, surveys and content analysis. The study followed the cross-sectional design as a microcosm of the survey, since data were collected at a single point in time in a community setting (Ross 2005:23; Gay, Mills and Airasian 2006:348). In short, the research method for this study was informed by the quantitative approach encompassing nonexperimental design, which subsequently, embraced the survey design.

The survey design is a microcosm of the quantitative non-experimental design (Maree 2007:34). Non-experimental research designs describe things that have occurred and examine relationships between things without any direct manipulation of conditions that are experienced. Generally, surveys are usually quantitative in nature, since they generate numerical data (Cohen, Manion and Morrison 2000:171). Surveys are used frequently in educational research to describe attitudes, beliefs, opinions, and other types of information (McMillan and Schumacher 2010:22). Unlike qualitative research, where design elements are worked out during the course of the study, the advantage of surveys is that they specify in advance the hypothesis, measurement and sampling measures. Maree (2007:157) argues that surveys are relatively cheap and easy to do. The respondents completed the questionnaires at their convenient times (Maree 2007:157; De Vos et al. 2002:174). The respondents also checked personal records where such information was required. The population for the study comprised women who are entrepreneurs in rural areas in the Mpumalanga Province of the Republic of South Africa. In order to sample the respondents for the study, papers with an inscription of the area's code were placed in a hat according to their locations. The required number of locations from each of the regions was drawn from the container forming a total sample of 150 rural women. The questionnaire is 'economical, has the same questions for all the respondents and can ensure anonymity' (McMillan and Schumacher 2010:195).

\section{Data Collection}

A structured questionnaire, as a data collection technique, was used to collect the women's opinions. Data were collected by means of a written questionnaire, which was placed in an envelope at the Local Municipality Offices together with a cover letter or letter of transmittal outlining the study (McMillan and Schumacher 2010:237). The envelopes were distributed to the municipal managers. Also, an explanatory note was enclosed in the envelopes requesting the municipal managers to inform the researcher when questionnaires were returned. The questionnaires were coded using municipal codes, to ensure that follow-up measures were precise and focused.

\section{Data Analysis and Interpretation}

According to Cohen, Manion and Morrison (2000:147) data analysis involves organising, accounting for and explaining the data. In retrospect, the research approach for the study is quantitative. Quantitative research relies heavily on numerical data in reporting results (Maree 2007:255). The study employed descriptive statistics to summarise and present the data. McMillan and Schumacher (2010:149) contend that 'the use of descriptive statistics is the most fundamental way to summarise data, and it is indispensable in interpreting the results of quantitative research'. In this study, descriptive statistics was used to summarise, organise and reduce large numbers of observations extricated from the participants' questionnaires. The statistics transformed a set of numbers or observations into indices that described or characterised the data.

Descriptive analysis encompasses univariate analysis (De Vos et al. 2002:225). Univariate analysis was employed to summarise the data on a single characteristic or variable, which is the dependent variable e.g. mean, median, mode, standard deviation, frequency distribution and percentages (McMillan and Schumacher 2010:151 and Ross 2005:31). In order to determine significant differences by strata (between regions and between locations), a t-test was used which compares means (Bluman 2006:448). The t-test was used to compare male and female respondents. The mean and 
standard deviation was applied to all questions in the questionnaire.

\section{Research Findings and Discussions}

\subsection{The Concept of Entrepreneurs}

The concepts of entrepreneur and entrepreneurship have been defined from many different perspectives by scholars and business executives. Carnall (2004:11) draws the following distinction between entrepreneurs and small business owners, "an entrepreneur is an individual who establishes profit and growth. However, a small business owner is an individual who establishes and manages a business for the principal purpose of furthering personal goals". Holt (2002:7) agrees also with Carnal and states that "...the word entrepreneur has its origin in the $17^{\text {th }}$ century French word "entrepreneur" which referred to individual commissioned to undertake a particular commercial project. Murphy (2008:17) confirmed also that "...an entrepreneur is a person who has possession of a new enterprise, venture or idea and assumes significant accountability for the inherent risks and the outcome".

\subsection{Small Business}

A small business is an individual endeavor which is established and managed for the principal purpose of furthering personal goals. This entrepreneurial small medium enterprise owner will be more inclined towards creativity (Carnall 2004:11).This means that entrepreneurship is the process of conceptualizing, organizing, launching and through innovation nurturing a business opportunity into a potentially high growth venture in a complex, unstable environment (Rwigema and Venter, 2005: 6a ; Kroon, 2006). Diseko (2008:7) concurs with Carnall and states that " $\ldots$ a small business is a business that is privately owned and operated, with a small number of employees and relatively low volumes of sales". Gideon(2003;07) agrees with Carnall and states that a small business is a business that is privately owned and operated, with a small number of employees and relatively low volumes of sales.

\subsection{Rural Entrepreneurship}

Through much of its history, rural South Africa has been home to small-town merchants, talented crafts people and progressive farmers, all willing to take the risks necessary to build their business and live the life of their choice. It is a legacy of entrepreneurship and small business ownership of which rural people and the provinces in South Africa can be proud of. Yet, the contributions of these entrepreneurs have often been obscured by the manufacturing empires that emerged around textiles, in the early 1900s. By the middle of the $20^{\text {th }}$ century, Mpumalanga province had become the most underdeveloped province in the Eastern part of South Africa and, as a result, was unable to provide jobs for thousands of its people in the rural part of the province (Evans and Russel 2002). However, previous researches show that failure of government assistance programs has been attributed to uneven geographical coverage, an inadequate number of service providers and or programs, the top-down approach to service delivery, low awareness, and gaps between the needs of entrepreneurs and the types of services offered. Weak local government support initiatives have also been highlighted as a major problem (Chandra, Moorty Ngamnou, Rajaranam and Schaefer, 2001)

According to Burns (2007:08) the following precautions need to be followed: When starting a business, it is important to have some management skills. Rural women entrepreneurship assists in improving the entrepreneurial and technical skills by strengthening relevant support to institutions and service providers and promotes human security by supporting entrepreneurship to enable disadvantaged population groups to seize economic opportunities. This article thus focused on the various determinants that influenced rural women entrepreneurs in general, while the main focus was on how the determinants mentioned above have affected the rural women entrepreneurs' small-scale business of the Mpumalanga .

\subsection{Present Factors Influencing Rural Women Entrepreneurs}

The present state of rural women entrepreneurship across the world and in South Africa in particular, seems to be influenced largely by the factors examined below in detail. 


\subsubsection{Business Skills}

Business success often depends on the existence of an enabling environment on one hand and the possession of skills and competencies by the entrepreneur on the other. Business skills are perceived differently by different scholars as presented below. The (www.businessdictionary.com/definition/skill.html )defines skills as abilities and capacities acquired through deliberate, systematic, and sustained effort to smoothly and adaptively carryout complex activities or job functions involving ideas (cognitive skills), things (technical skills), and/or people (interpersonal skills). The above views suggest that skills are acquired through training which brings in the importance of education to the success of female led businesses in rural areas.

\subsubsection{Functions of the Business Skills}

Business skills development among business executives in general and women entrepreneurs in particular are important in the following ways: Skilled business women are capable of supporting national poverty reduction strategies through building affordable and effective support services for micro and small enterprises in rural areas and strengthening the capacity of public and private-sector support institutions to identify and alleviate the constraints faced by women entrepreneurs, and also provide information and training to civil society (Moe (2003:71). White women were not afforded as many opportunities as white men during apartheid. It was black rural women who suffered the most under colonial and apartheid rule, having no skills. One of the key training needs is financial management skills which include, bookkeeping, how to read and prepare financial statements and taxation.

\subsubsection{Skills Development}

According to Jack, (2007:272) Skills development and organizational transformation are at the heart of Black economics empowerment, as business education will lead to the financial growth of Black people, White people with assets, in South Africa, were not necessarily given those assets, in most circumstances they had to work hard for them. He further indicates that "Skills development goes hand in hand with employment equity and together they are termed human resource development, the legacy of the past has resulted in black people being left out of the mainstream economy and in many cases skills development from school education level was denied, through job reservation and other policies black people's growth was restricted, thus limiting the scope for developing skills needed to perform more complex jobs and businesses.

Ramaphosa concurs with Jack by stating several principles on skills development, such principles are as follows:-

- Skills development is undertaken after an assessment of the skills needed to enable Black people to perform their current role better and allow them to progress to more challenging positions within the enterprise.

- It is essential that entrepreneurs apply the new skills to ensure that contribute to the efficiency of the enterprise and, ultimately its financial success.

- The enterprise must focus on developing critical and technical skills required in its core functions.

- The key factor in integrating Black entrepreneurs into the mainstream economy is the development of their skills to allow them to participate meaningfully in business.

- The focus on skills development should be on those skills that are critical to the core business of the enterprise as opposed to focusing only on peripheral support skills.

- In a financial services concern black entrepreneurs must be trained and encouraged to participate in executing deals, structuring corporate finance and crafting structured finance instruments.

Business Unity South Africa (BUSA) 2005:05 gave both black and white business views into each other's attitudes to important issues like skills development. Many black entrepreneurs suspected that their white employers were not interested in allowing them to acquire skills to move upward. It is clear that, without undermining the importance of the support functions in enterprises, the involvement of black entrepreneurs in these areas alone will not enable them to drive the engine of the economy.

\subsubsection{Role of Education in Entrepreneurial Development}

Education is the backbone to the emancipation of rural women entrepreneurs, and opportunities for rural women are too few and far between to have much impact. Blau (2006:79) seems to make a similar point when he claims that "........ It is 
ironic that there is a view that white women can impart skills to black women, "that says that black rural women have no skills, and have nothing to bring to the table". Small scale rural business activities are increasing important for livelihood in developing countries, but require the development of new skills and relationships (Sizo0 2007;13). Niemand (2003;13) cites the following on skills development, micro and small scale enterprises (M.S.E) are the seedbeds for a broad development of the private sector and create a large number of self-employment and income opportunities, forming the foundation for the national economy and social development at the grass roots.

\subsubsection{Business Planning}

Business planning in the modern sense has a fairly long history; business planning with modern characteristics was already practiced in the mining industry in France in the $19^{\text {th }}$ century (Mintzberg 2007:12). He further points out that "business planning is a simple statement of objectives, including indications of methods to be used to achieve them, or it may be a very extensive planning process in which every element of the corporation routinely takes part (Mintzberg, 2007:14)

\subsubsection{Pros and Cons of Business Planning.}

The primary negatives associated with modern business planning, arise chiefly from four factors:

1. The bureaucratization of the process and the resulting high costs associated with it.

2. Uncertainty brought about by rapid change.

3. Performance evaluation issues which, many claim, stifle innovation and result in unproductive gamesmanship.

4. Planning process poorly matches the quarterly stock market cycle.

The general lack of planning for resources by rural women entrepreneurs is a great contributing factor to the development of rural women entrepreneurs in rural regions. According to Yin, (2004:173), those rural women entrepreneurs may have a structure in the form of a committee with a coordinator or managers and constitution yet they still do not have business plans. He cites further problems and claims that "............ Business plans are important because it is often on the basis of a good plan that funders consider applications for funding". It would be important that training on business plan compilation becomes part of management training (Moe, 2003:208). Rwigema (2004) states that "... planning can make the difference between success and failure of your business. Poor planning is repeatedly cited among the top reasons for business failure.

\subsubsection{Concept of Corporate Planning}

Ackoff (2002:31) confirms that "Forecasting uncertainties are the very essence of modern business planning; therefore it provides the measurements that justify the planning effort". He further indicates that "the operating manager planning for his or her unit makes the best possible projections about future costs, sales, capital needs, and returns, the corporate budget, including not just cost projections but every aspects of future financial outcome. It is clear that business planning, in some form is here to stay as highly evolved and complex planning cycles are in use in most corporations.

\subsubsection{Markets and Marketing}

According to Kuratko (2001:99) a market is any arrangement in which some people sell a good or service and others buy it. However, for markets to function they need a range of other players supporting the core buyers and sellers. According to Vorster (2004:60) a market is any one of a variety of different systems, institutions, procedures, social relations and infrastructures whereby persons trade. Steyn (2008:4) defines marketing as the process of planning and executing the conception, pricing, promotion and distribution of goods, services and ideas to create exchanges that satisfy individual and organization objectives. Hendry (2004:02) concurs with Steyn and states that "... marketing is the process by which companies create customer interest in products or services. The issue of markets and marketing strategy are closely related to business planning. According to Mfono (2008:17) business plans require that business undertake market research studies that will provide estimates of potential market size and the marketing strategy of the business.

\section{Conclusions and Recommendations}

The study concludes that training and development is a major challenge failing rural women in the Mpumalanga Province 
of the Republic of South Africa. Financial funding is another major problem faced by rural women entrepreneurs. Infrastructure development is of importance to the success of the rural women entrepreneurs.

There is a need for encouraging active participation among rural women into business as they form key targets for economic development in rural areas. Partnerships with relevant organisations such as Umsobomvu Youth Fund would be important for the realisation of this objective as this is one of the financial institutions that can be able to support rural women in business endeavours.

\section{References}

Ackoff, Z.P 2002. Concept of corporate planning. USA. John and Sons.

Blau, F.D. Ferber, M.A and Winkler, A.E. 2006. The economics of women, men and work, 5th edition. New Jersey: Pearson education, INC, Upper Sapple River.

Bluman, A. G. 2006. Elementary statistics: a step by step approach, 3rd edition. New York: McGraw-Hill.

Burns, K.D. 2007. Methods of Social Research, 3rd edition. New York: Free Press.

Carnal, C.A. 2004. Managing change in Organizations. Prentice Hall, Europe.

Chandra, V. Moorty, S. Nganou, J. Rajarajnam, B and Schefer, K. 2001. Growth and employment in South Africa Report 2. Evidence from the small meduim and enterprise firm survey.

Cohen, L., Manion, L. and Morrison, K. 2000. Research methods in education, $5^{\text {th }}$ edition. London: RoutledgeFalmer.

De Vos, A. S., Strydom, H., Fouché, C. B. and Delport, C. S. L. 2002. Research at grass roots: for the social sciences and human service professions, $2^{\text {nd }}$ edition. Pretoria: Van Schaik.

Diseko, F. 2008. We can put it right. The Entreprenuer February 2008.

Evans, J.R and Rusesel, P. 2002. The Southern African Migration. Durban Butterworhts.

Gay, L. R., Mills, G. E. and Airasian, P. 2006. Educational research: competencies for analysis and applications, $8^{\text {th }}$ edition. New Jersey: Pearson Educational, Inc.

Gideon, K. and Morgan, C. 2003. Entrepreneurial thinking. Pretoria Academia.

Heneveld, W. and Craig, H. 1996. Schools count: World Bank Project Designs and Quality of Primary Education in Sub-Saharan Africa. D.C.: World Bank.

Howie, S. J. 2003. Language and other background factors affecting secondary pupils' performance in mathematics in South Africa. African Journal of Research in SMT Education 7:1-18.

Jack, P. 2007. Managers Guide to making Decisions about entrepreneurship systems. Hoboken. N.J. USA: John Wiley and sons.

Kuratko, D. 2001. Top 300 national companies. Oxford. Cape Town: Top Companies Publishing.

Maree, K. 2007. First steps in research. Pretoria: Van Schaik.

McMillan, J. H. and Schumacher, S. 2010. Research in education: evidence-based inquiry, $7^{\text {th }}$ edition. Boston: Pearson.

Mintzberg L. 2007, The Structuring of Organizations. New Jesery: Prentice Hall .

Murphy, K. 2008 Rural Women Entrepreneurs. Pretoria: Kagiso Publishers.

Niemand, R. 2003. Practice of social research. Cape Town: Oxford.

Ross, K. N. 2005. Quantitative research methods in educational planning. Accessed 06/09/2013 at http://www.unesco.org/iiep

Rwigema, $\mathrm{H}$ and Venter, R. 2005. Advanced Entrepreneurship. Cape Town. Oxford University Press.

Shavelson, R. J., McDonnell, L. M. and Oakes, J. 1987. Indicators for monitoring Mathematics and Science education: a sourcebook. USA: The RAND Corporation. 